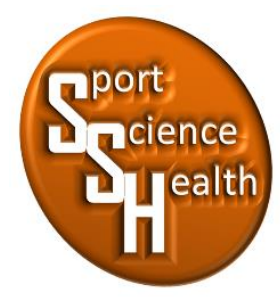

ISSN 2715-3886

\title{
Pengaruh Latihan Dribble Zig-Zag terhadap Peningkatan Keterampilan Dribble Bola Basket Bagi Peserta Kegiatan Ekstrakurikuler Bola Basket SMA
}

\author{
Desi Fatmawati ${ }^{1 \star}$, Siti Nurrochmah², Febrita Paulina Heynoek ${ }^{3}$ \\ 1,2,3 Jurusan Pendidikan Jasmani, Kesehatan dan Rekreasi, Fakultas IImu Keolahragaan, \\ Universitas Negeri Malang, Jalan Semarang No 5, Malang, Jawa Timur, 65145, Indonesia \\ *Penulis koresponden: fatmawatidesi0304@gmail.com, 082232964696
}

Artikel diterima: 8 Januari 2020; direvisi: 16 November 2020; disetujui: 23 November 2020

\begin{abstract}
The results of preliminary observations of the basketball zigzag dribble test, as many as $60 \%$ of participants could not do it correctly and accurately. The purpose of this study was to examine the effect of basketball dribble zigzag training using poles and cardboard on improving basketball dribble skills in basketball extracurricular activities at SMA Nasional Malang. The experimental research design, a sample of 40 participants was taken using a purposive proportional systematic random sampling technique from a total of 40 male participants. Fcount 76.22 is more than Ftable $\alpha$ equal to 0.05 4.17. While the results of the advanced test of the LSD technique of dribbling zigzag basketball practice using $T$ count -6.283 and $T$ table 1.685, the results of the advanced test of the LSD technique of dribble zigzag basketball training using cardboard T count 11.364 and $T$ table 1.685, there is an effect of dribble training. zigzag basketball using poles and cardboard to improve basketball dribble skills. A basketball zigzag dribble using a pole is better than a basketball zigzag dribble exercise using cardboard.
\end{abstract}

Keyword: zigzag dribble, basketball dribble skills

\begin{abstract}
Abstrak: Hasil observasi awal tes dribble zig-zag bola basket, sebanyak $60 \%$ peserta tidak bisa melakukan secara tepat dan akurat. Tujuan penelitian ini adalah untuk mengkajipengaruh latihan dribble zig-zag bola basket menggunakan tiang dan kardus terhadap peningkatan keterampilan dribble bola basket pada peserta kegiatan ekstrakurikuler bola basket SMA Nasional Malang. Rancanagan penelitian eksperimen, sampel 40 peserta diambil menggunakan teknik purposive proporsional systematic random sampling dari jumlah 40 peserta laki-laki. $F_{\text {hitung }}$ 76,22 lebih dari $F_{\text {tabel a sama dengan } 0,05}$ 4,17. Sedangkan hasil uji lanjut teknik LSD latihan dribble zig-zag bola basket menggunakan tiang $T$ hitung $-6,283$ dan $T$ tabel 1,685, hasil uji lanjut teknik LSD latihan dribble zig-zag bola basket

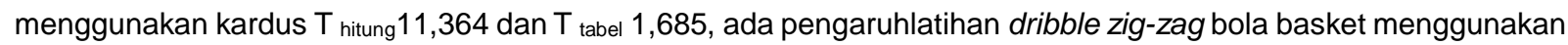
tiang dan kardus terhadap peningkatan keterampilan dribble bola basket. Latihan dribble zig-zag bola basket menggunakan tiang lebih baik dari pada latihan dribble zig-zag bola basket menggunakan kardus.
\end{abstract}

Kata kunci: dribble zig-zag, keterampilan dribble bola basket 


\section{PENDAHULUAN}

Dribble bola merupakan salah satu teknik dasar yang cukup memiliki peran penting dalam permainan bola basket, tidak heran jika para pengamat bola basket menyatakan bahwa mahirnya seorang pemain bola basket dapat dilihat pada bagaimana seorang pemain tersebut mendribble bola basket. Wahyuni (2013:498) dribble adalah membawa dribble bola basket kesegala arah dengan peraturan yang ada. Kegunaan dari dribble bola basket adalah mencari peluang serangan, menerobos pertahanan lawan, atau memperlambat tempo permainan. Selain itu kemampuan dribble bola basket diperluka oleh pemain bola basket dalam menghadapi situasi tertentu dan kondisi pertandingan yang menuntut unsur agility dalam bergerak untuk menguasai bola maupun dalam bertahan untuk menghindari benturan yang mungkin terjadi.

Berdasarkan hasil wawancara dan studi awal peneliti di SMA Nasional Malang yang beralamat di Jl. Sudanco Supriyadi 50 Malang, kegiatan ekstrakurikuler bola basket diikuti oleh 30 siswa dari kelas X, XI, XII IIS dan MIA. Dilaksanakan tiga kali seminggu mulai hari senin, rabu dan jumat mulai pukul $15.00 \mathrm{WIB}-17.00 \mathrm{WIB}$. SMA Nasional Malang merupakan salah satu diantara banyak sekolah yang mengutamakan prestasi akademik dari pada prestasi non-akademik, khususnya bola basket masih belum berprestasi karena tidak terlalu diutamakan.

Berdasarkan fakta empiris dari studi awal oleh peneliti bahwa kemampuan menggiring bola (dribble) yang dilakukan siswa peserta ekstrakurikuler bola basket belum terlalu baik, dribble bola belum dapat dikuasai secara baik dan benar oleh peserta kegiatan ekstrakurikuler bola basket SMA Nasional Malang. Peserta kegiatan ekstrakurikuler bola basket masih banyak yang melakukan kesalahan saat dribble bola seperti masih banyak peserta yang melihat bola pada saat dribble bola basket, bola tidak dilindungi saat dribble bola basket, peserta kesulitan mengontrol bola saat dribble bola basket, peserta kurang lincah dan cepat saat dribble bola, bahkan terlihat belum adanya koordinasi gerak kaki dan tangan saat dribblebola basket, ada pula yang sampai bertabrakan saat dribble bola ketika gamebola basket.

Tujuan penelitian adalah: (1) Untuk mengetahui pengaruh latihan dribble zig-zag bola basket menggunakan tiang terhadap peningkatan keterampilan dribble bola basketpeserta kegiatan ekstrakurikuler bola basket SMA Nasional Malang. (2) Untuk mengetahui pengaruh latihan dribble zig-zag bola basketmenggunakan kardus terhadap peningkatan keterampilan dribble bola basket peserta kegiatan ekstrakurikuler bola basket SMA Nasional Malang. (3) Untuk latihan dribble zig-zag bola basket menggunakan tiang dan kardus yang lebih meningkatkan keterampilan dribble bola basket peserta kegiatan ekstrakurikuler SMA Nasional Malang.

\section{Keadaan Hipotesis dan Korespondensi Mereka dengan Desain Penelitian}

Lari zig-zag adalah suatu macam bentuk latihan yang dilakukan dengan gerakan berkelok-kelok melewati rambu-rambu yang telah di siapkan, dengan tujuan untuk melatih kemampuan berubah arah dengan cepat (Ahmad, 2018; Dionisius Wora, I Putu Adiatmika, Oktovianus Fufu, N.Adiputra, Made Muliarta, 2017). Lari zig zag merupakan bentuk latihan berlari secepat cepatnya melalui lintasan yang berbelok belok dan kembali ke tempat star. Gerakan diulang sebanyak 6 sampai 8 kali (Garcia-Gil et al., 2018). Dari pendapat tersebut peneliti menyimpulkan bahwa dribblezig-zag adalah gerakan dribble yang dilakukan secara berkelok kelok sesuai dengan rintangan yang telah dipersiapkan.

Tujuan latihan dribble zig-zag bola basket adalah untuk menguasai keterampilan dribble, menghindar dari berbagai halangan baik orang maupun benda yang ada di sekeliling. Cara melakukan dribble zig-zag bola basket yaitu peserta didik membawa lari bola dengan dibblebola basket kemudian berlari berkelok-kelok mengikuti rintangan yang telah dipersiapkan. Dalam penelitian ini rintangan dribble zig-zag bola basketdibedakan menjadi dua yaitu menggunakan tiang dan menggunakan kardus. Maksudnya yaitu, latihan dribble zig-zag tiang adalah gerakan dribble berkelok-kelok mengikuti lintasan berupa tiang berjumlah 10 tiang dan jarak antar tiang 1,5 meter, Latihan dribble zig-zagbola basket menggunakan kardus adalah dribble zigzag bola basket yang dilakukan dengan mengikuti lintasan kardus secara berkelok-kelok berjumlah 10 kardus dan jarak antar kardus 1,5 meter. Latihan dribble zig-zag bola basket menggunakan tiang dan latihan dribble zig-zag menggunakan kardus digunakan sebagai bahan dalam penelitian ini, dan disesuaikan dengan program latihan yang nantinya akan digunakan untuk meningkatkan dribble bola basket siswa peserta kegiatan ekstrakurikuler bola basket SMA Nasional Malang. 


\section{METODE}

Rancangan yang digunakan berupa rancangan eksperimen, berupa Randomized Control Group PretestPosttest Desain yaitu rancangan terdiri dari satu perlakuan atau lebih dan sebuah kontrol (McCusker \& Gunaydin, 2015). Variabel yang diteliti meliputi: (a) Variabel terikat berupa peningkatanketerampilan dribble bola basket, (b) Variabel bebas berupa: (a) Latihan dribble zig-zag bola basket menggunakan tiang, (b) Latihan dribble zig-zag bola basket menggunakan kardus, (3) Variabel terkendali berupa (a) Jenis kelamin yaitu lakilaki (b) Bentuk perlakuan yaitu dribble zig-zag bola basket menggunakan tiang dan menggunakan kardus, (c) Orang coba penelitian : peserta kegiatan ekstrakurikuler bola basket SMA Nasional Malang.

Populasi dalam penelitian ini adalah seluruh peserta kegiatan ekstrakurikuler bola basket SMA Nasional Malang yang berjumlah 40 orang. Pembagian kelompok menggunakan teknik ordinal pairing matching menjadi 2 kelompok yaitu kelompok eksperimen latihan perlakuan dribble zig-zag bola basket menggunakan tiang berjumlah 20 orang atlet dan kelompok eksperimen latihan dribble zig-zag bola basket menggunakan kardus berjumlah 20 orang atlet.

Instrumen penelitian ini berupa instrumen tes dan nontes. Jenis instrumen tes yang digunakan berupa tes dribble bola basket yaitu tes dribble zig-zag bola basket dilakukan dua kali setiap percobaan dalam satuan detik. Pengumpulan data dalam penelitian ini menggunakan teknik pengukuran bentuk tes keterampilan berupa tes dribble zig-zag bola basket dan observasi, teknik eksperimen digunakan untuk memberikan perlakuan pada kelompok eksperimen, serta dokumentasi.

Data yang sudah terkumpul dianalisis dengan statistika inverensial satu jalan Menghitung rata-rata tes awal (pretest) dan tes akhir (posttest) menggunakan metode statistik yaitu dengan bantuan komputer program exel, sebelum analisis data teknik analisis varian dilakukan dengan bantuan jasa komputer program exel maka persyaratan-persyaratan dalam anava harus dipenuhi yaitu uji normalitas dan uji homogenitas.

\section{HASIL}

Berdasarkan data hasil tes awal (pretest) kecepatan dribble zig-zag bola basket menggunakan tiang peserta kegiatan ekstrakurikuler bola basket SMA Nasional Malang tersebut, diperoleh rata-rata hitung (mean) sebesar 11,87 detik, simpangan baku (SB) sebesar 2,78 detik, dan distribusi frekuensi seperti ditunjukkan pada Tabel1. berikut.

Tabel 1. Distribusi Frekuensi Tes Awal (pretest) Kelompok Latihan Dribble Zig-zag Bola Basket menggunakan Tiang

\begin{tabular}{ccccc}
\hline No. & $\begin{array}{c}\text { Interval Hasil Kecepatan Dribble Bola } \\
\text { Basket (detik) }\end{array}$ & $\begin{array}{c}\text { Frekuensi } \\
\text { Absolut }\end{array}$ & $\begin{array}{c}\text { Frekuensi Relatif } \\
(\%)\end{array}$ & Kategori \\
\hline 1. & $7-8.5$ & 4 & 20.0 & $\begin{array}{c}\text { Sangat } \\
\text { cepat }\end{array}$ \\
2. & $9-10.5$ & 6 & 30.0 & Cepat \\
3. & $11-12.5$ & - & - & Sedang \\
4. & $13 .-15.5$ & 10 & 50.0 & Lambat \\
\hline & Jumlah & 20 & 100.0 & \\
\hline
\end{tabular}

Berdasarkan data hasil tes awal (pretest) kecepatan latihandribble zig-zag bola basketmenggunakan kardus peserta kegiatan ekstrakurikuler bola basket SMA Nasional Malang tersebut, diperoleh rata-rata hitung (mean) sebesar 12,88 detik, simpangan baku (SB) sebesar 2,43 detik, dan distribusi frekuensi seperti ditunjukkan pada Tabel 2. berikut. 
Tabel 2. Distribusi Frekuensi Tes Awal (pretest) Kelompok Latihan Dribble Zig-zag Bola Basket menggunakan Kardus

\begin{tabular}{llrlll}
\hline No. & \multicolumn{2}{l}{ Interval Hasil kecepatan } \\
dribble bola & basket & Frekuensi & Frekuensi & Relatif \\
Absolut & $(\%)$ & Kategori \\
\hline 1. & $7-8.5$ & 1 & 5.0 & Sangat cepat \\
2. & $9-10.5$ & 3 & 15.0 & Cepat \\
3. & $11-12.5$ & 6 & 30.0 & Lambat \\
4. & $13-15.5$ & 10 & 50.0 & Sangat lambat \\
\hline & Jumlah & 20 & 100 & \\
\hline
\end{tabular}

Berdasarkan data hasil tes akhir (post-test) kecepatan latihan dribble zig-zag bola basket menggunakan tiang peserta kegiatan ekstrakurikuler bola basket SMA Nasional Malang tersebut, diperoleh rata-rata hitung (mean) sebesar 9,60detik, simpangan baku (SB) sebesar 2,9detik, dan distribusi frekuensi seperti ditunjukkan pada Tabel 4.4 berikut

Tabel 3. Distribusi Frekuensi Tes Akhir (post-test) Kelompok Latihan Dribble Zig-zag Bola Basket menggunakan Tiang

\begin{tabular}{ccccc}
\hline No. & $\begin{array}{c}\text { Interval Hasil Kecepatan Dribble } \\
\text { Bola Basket (Detik) }\end{array}$ & $\begin{array}{c}\text { Frekuensi } \\
\text { Absolut }\end{array}$ & $\begin{array}{c}\text { Frekuensi } \\
\text { Relatif }(\%)\end{array}$ & Kategori \\
\hline 1. & $7-8.5$ & 13 & 65.0 & $\begin{array}{c}\text { Sangat } \\
\text { cepat }\end{array}$ \\
2. & $9-10.5$ & - & - & $\begin{array}{c}\text { Cepat } \\
\text { Kurang } \\
\text { cepat } \\
\text { Lambat }\end{array}$ \\
3. & $11-12.5$ & 3 & 15.0 & \\
4. & $13 .-15.5$ & 4 & 20.0 & \\
\hline
\end{tabular}

Berdasarkan data hasil tes akhir (post-test) kecepatan latihan dribble zig-zag bola basket menggunakan kardus peserta kegiatan ekstrakurikuler bola basket SMA Nasional Malang tersebut,diperoleh rata-rata hitung (mean) sebesar 11,33 detik, simpangan baku (SB) sebesar 2,36 detik, dan distribusi frekuensi seperti ditunjukkan pada Tabel 4. berikut.

Tabel 4. Distribusi Frekuensi Tes Akhir (post-test) Kelompok Latihan Dribble Zig-zag Bola Basket menggunakan Kardus

\begin{tabular}{lllll}
\hline No. & $\begin{array}{c}\text { Interval Hasil Kecepatan Dribble } \\
\text { Bola Basket (Detik) }\end{array}$ & $\begin{array}{l}\text { Frekuensi } \\
\text { Absolut }\end{array}$ & $\begin{array}{l}\text { Frekuensi Relatif } \\
(\%)\end{array}$ & Kategori \\
\hline 1. & $7-8.5$ & 3 & 15.0 & Sangat cepat \\
2. & $9-10.5$ & 5 & 25.0 & Cepat \\
3. & $11-12.5$ & 2 & 10.0 & Sedang \\
4. & $13 .-15.5$ & 10 & 50.0 & Lambat \\
\hline Jumlah & & 20 & 100 & \\
\hline
\end{tabular}

Berdasarkan data hasil tes akhir (post-test) kecepatan latihan dribble zig-zag bola basket menggunakan tiang dan latihan dribble zig-zag bola basket menggunakan kardus peserta kegiatan ekstrakurikuler bola basket SMA Nasional Malang tersebut, diperoleh rata-rata hitung (mean) sebesar 9,60 detik, simpangan baku (SB) sebesar 2,9 detik, dan distribusi frekuensi seperti ditunjukkan pada Tabel 5. berikut. 
Tabel 5. Distribusi Frekuensi Tes Akhir (post-test) Kelompok Latihan Dribble Zig-zag Bola Basket menggunakan Tiang dan Latihan Dribble Zig-zag Bola Basket menggunakanKardus

\begin{tabular}{ccccc}
\hline $\begin{array}{c}\text { No. } \\
\text { Kecepatan DribbleBola } \\
\text { Basket (detik) }\end{array}$ & $\begin{array}{c}\text { Frekuensi Absolut Dribble Zig-zag Bola } \\
\text { Basket Menggunakan Kardus }\end{array}$ & Kategori \\
\hline & & Tiang & Kardus & \\
\hline 1. & $7-8.5$ & 13 & 3 & $\begin{array}{c}\text { Sangat } \\
\text { cepat }\end{array}$ \\
2. & $9-10.5$ & - & 5 & Cepat \\
3. & $11-12.5$ & 3 & 2 & Sedang \\
4. & $13 .-15.5$ & 4 & 10 & Lambat \\
\hline
\end{tabular}

\section{Pengerahan}

Berdasarkan tujuan penelitian yang telah dirumuskan pada bab I, dan setelah data dari masing-masing variabel yang diteliti, yaitu variabel bebas berupa latihan dribble zig-zag bola basket menggunakan tiang $\left(\mathrm{X}_{1}\right)$, latihan dribble zig-zag bola basket menggunakan kardus $\left(\mathrm{X}_{2}\right)$, dan variabel terikat berupa peningkatan keterampilan dribble bola basket (Y),

\section{Statistik dan Analisis Data}

\section{Hasil Analisis Uji Normalitas Data}

Untuk dapat mengetahui normalitas sebuah data, maka dilakukan analisis data berupa uji normalitas data. Hal ini dilakukan untuk mengetahui apakah data yang diperoleh tersebut berasal dari data yang berdistribusi normal atau tidak. Penghitungan uji normalitas data tersebut dilakukan dengan menggunakan teknik Lillifors dan menggunakan taraf signifikansi a sama dengan 0,05 . Hasil untuk uji normalitas data tersebut disajikan pada Tabel 6. berikut ini.

Tabel 6. Hasil Analisis Uji Normalitas Data Tiap Kelompok Penelitian

\begin{tabular}{|c|c|c|c|c|c|c|}
\hline Kelompok & Tes & $\mathrm{N}$ & Mean & $\mathrm{L}$ hitung & $\mathrm{L}$ tabel & Keterangan \\
\hline \multirow{2}{*}{$\begin{array}{l}\text { Latihan dribble } \\
\text { zig-zag bola } \\
\text { basket } \\
\text { menggunakan } \\
\text { tiang }\end{array}$} & Awal & 20 & 11,89 & 0,0967 & 0,1900 & $\begin{array}{l}\text { Lhit kurang dari } L_{\text {tab }} \text { data } \\
\text { berdistribusi (normal) }\end{array}$ \\
\hline & Akhir & 20 & 9,595 & 0,1350 & 0,1900 & $\begin{array}{l}\text { Lhit kurang dari Ltab data } \\
\text { berdistribusi (normal) }\end{array}$ \\
\hline \multirow{2}{*}{$\begin{array}{l}\text { Latihan dribble } \\
\text { zig-zag bola } \\
\text { basket } \\
\text { menggunakan } \\
\text { kardus }\end{array}$} & Awal & 20 & 12,655 & 0,0857 & 0,1900 & $\begin{array}{l}\text { Lhit kurang dari } \text { Ltab } \text { data } \\
\text { berdistribusi (normal) }\end{array}$ \\
\hline & Akhir & 20 & 11,33 & 0,1251 & 0,1900 & $\begin{array}{l}\text { Lhit kurang dari } L_{\text {tab }} \text { data } \\
\text { berdistribusi (normal) }\end{array}$ \\
\hline
\end{tabular}

\section{Keterangan :}

Mean sama dengan Rata-rata hitung

$\mathrm{L}$ tabel sama dengan Tabel $\mathrm{L}$ untuk nilai kritis uji Lillifors

$\mathrm{N} \quad$ sama dengan Jumlah sampel

Berdasarkan uraian hasil analisis uji normalitas tiap kelompok penelitian pada Tabel 6 . tersebut dapat disimpulkan bahwa data dari tiap kelompok penelitian berdistribusi normal.

\section{Hasil Analisis Uji Homogenitas Varian dalam Populasi}

Analisis uji homogenitasvarian dalam populasi dilakukan terhadap data skor tes awal dengan tes akhir kelompok eksperimen latihan dribble zig-zag bola basket menggunakan tiang dan latihan dribble zig-zag bola basket menggunakan kardus dengan menggunakan teknik Hartly's max dengan taraf signifikansi a sama dengan 0,05 . Penghitungan lengkap uji homogenitas dapat di lihat pada lampiran. Sedangkan rangkuman 
hasil perhitungan ditunjukkan dalam Tabel 7 . berikut ini.

Tabel 7. Hasil Uji Homogenitas Skor Tes Awal dengan Tes Akhir Kelompok Eksperimen Kelompok Dribble Zig-Zag Bola Basket Menggunakan Tiang Dan Dribble Zig-zag Bola Basket Menggunakan Kardus

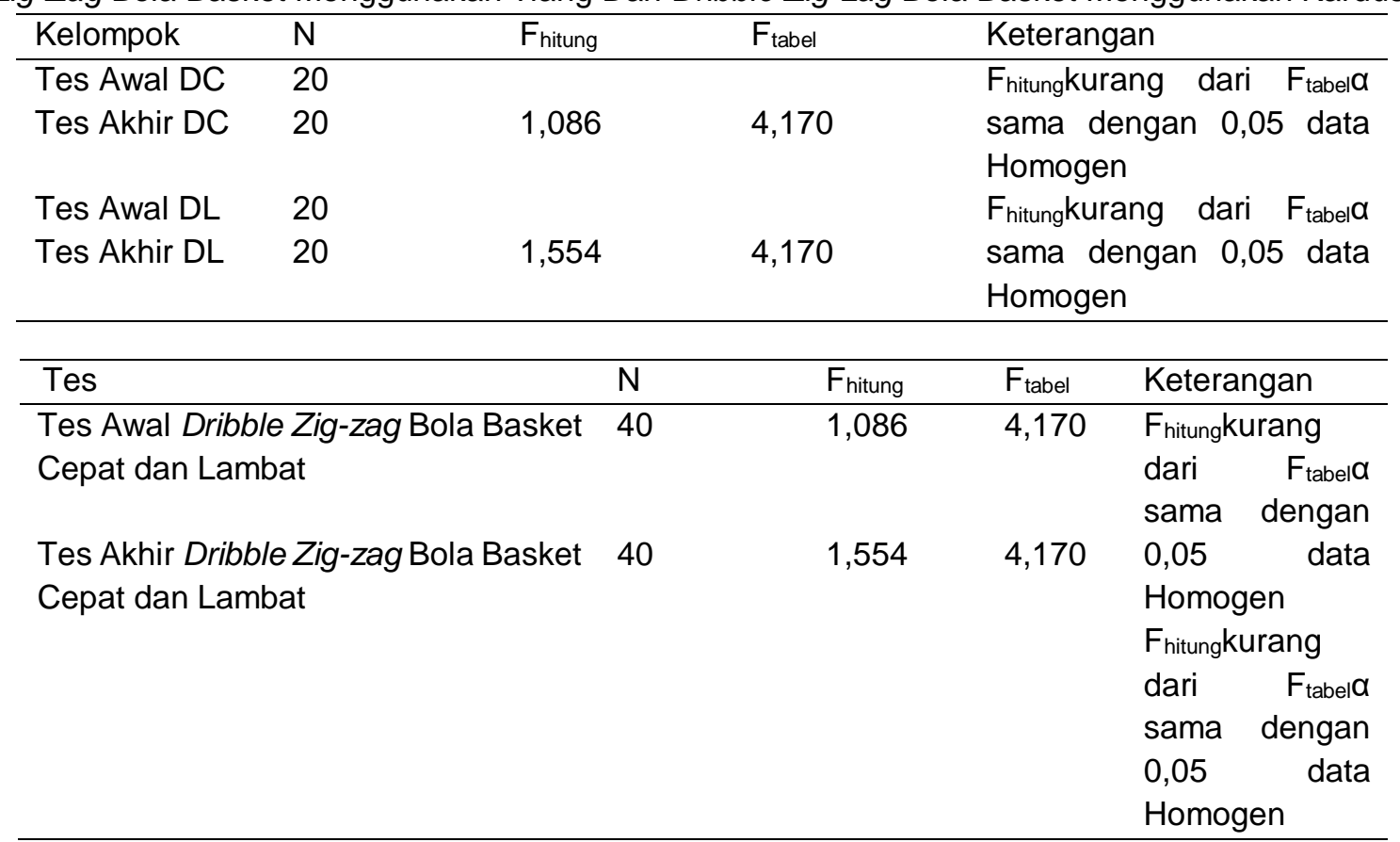

Keterangan :

Tes Awal DC sama dengan Tes awal dribble cepat

Tes Awal DL sama dengan Tes awal dribble lambat

Tes Akhir DC sama dengan Tes akhir dribble cepat

Tes Akhir DL sama dengan Tes akhir dribble lambat

$\mathrm{N} \quad$ sama dengan Jumlah sampel

Berdasarkan hasil penghitungan uji homogenitas pada Tabel 4.8 tersebut diperoleh harga $F_{\text {hitung }}$ untuk tes awal dan tes akhir kelompok eksperimen latihan lari zig-zag bola basket menggunakan tiang sebesar 1,086 dan $F_{\text {tabel }}$ sebesar 4,170 dengan taraf signifikansi $\alpha$ sama dengan 0,05 . Oleh karena $F_{\text {hitung sama dengan } 1,086}$ kurang dari $F_{\text {tabel }}$ sama dengan 4,170 maka, seluruh kelompok latihan latihan dribble zig-zagbola basketmenggunakan tiang berasal dari varian populasi yang homogen. Sedangkan untuk tes awal dan tes akhir kelompok eksperimen latihan dribble zig-zag bola basket menggunakan kardus diperoleh Fitung 1,554 dan $F_{\text {tabel }} 4,170$, dengan taraf signifikansi $\alpha$ sama dengan 0,05 . Oleh karena $F_{\text {hitung sama dengan } 1,554 \text { kurang }}$ dari $F_{\text {tabel }}$ sama dengan 4,170 maka, seluruh kelompok latihan dribblezig-zag bola basket menggunakan kardus berasal dari varian populasi yang homogen. Dengan demikian analisis varian (ANAVA) satu jalur dapat dilanjutkan.

Hasil uji normalitas pada penelitian ini menggunakan teknik lillifors (McNabb \& McNabb, 2018). Harga Fitung untuk tes awal dan tes akhir kelompok eksperimen dribble zig-zag bola basket menggunakan tiang sebesar 1,086 dan $F_{\text {tabel }}$ sebesar 4,170 dengan taraf signifikansi $\alpha$ sama dengan 0,05 . Oleh karena $F_{\text {hitung sama dengan }}$ 1,086 kurang dari $F_{\text {tabel }}$ sama dengan 4,170 maka, seluruh kelompok latihan dribble zig-zag bola basket menggunakan tiang berasal dari varian populasi yang homogen. Sedangkan untuk tes awal dan tes akhir kelompok eksperimen dribble zig-zag bola basket menggunakan kardus diperoleh $F_{\text {hitung }} 1,554$ dan $F_{\text {tabel }} 4,170$, dengan taraf signifikansi $\alpha$ sama dengan 0,05 . Oleh karena $F_{\text {hitung }}$ sama dengan 1,554 kurang dari $F_{\text {tabel }}$ sama dengan 4,170 maka, seluruh kelompok latihan dribble zig-zag bola basket menggunakan kardus berasal dari varian populasi yang homogen.

Hasil analisis tes awal (pretest) dengan tes akhir (post-test) kelompok latihan dribble zig-zag bola basket

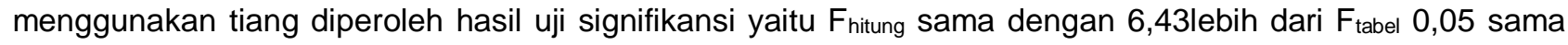
dengan 4,17, maka dari itu dapat disimpulkan bahwa ada pengaruh yang signifikan antara latihan dribble zigzag bola basket menggunakan tiang terhadap peningkatan ketrampilan dribble bola basket peserta ekstrakurikuler bola basket SMA Nasional Malang. 
Hasil uji-t berpasangan untuk kecepatan dribble zig-zag bola basket menggunakan tongkat dalam tabel 4.12

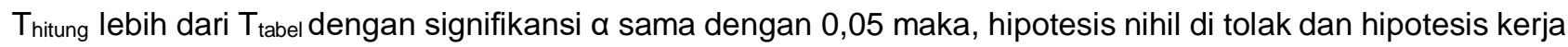
diterima, berarti terdapat perbedaan antara latihan dribble zig-zag bola basket menggunakan tiang saat pretest dan posttest.

Hasil analisis tes awal (pretest) dengan tes akhir (post-test) kelompok eksperimen latihan dribble zig-zag bola basket menggunakan kardus diperoleh hasil uji signifikansi yaitu $F_{\text {hitung }}$ sama dengan 4,19lebih dari $F_{\text {tabel }} 0,05$ sama dengan 4,17, maka dari itu dapat disimpulkan bahwa ada pengaruh yang signifikan antara latihan dribble zig-zag bola basket menggunakan kardus terhadap peningkatan ketrampilan dribble bola basket peserta ekstrakurikuler bola basket SMA Nasional Malang.

Bahwa latihan dribble zig-zag bola basket menggunakan kardusdalam tabel $4.12 \mathrm{~T}_{\text {hitung }}$ lebih dari $\mathrm{T}_{\text {tabel }}$ dengan signifikansi a sama dengan 0,05 maka, hipotesis nihil di tolak dan hipotesis kerja diterima, berarti terdapat perbedaan antara latihan dribble zig-zag bola basket menggunakan kardus saat pretest dan posttest.

Oleh karena $T_{\text {hitung }}$ lebih dari $T_{\text {tabel }}$ dengan signifikansi a sama dengan 0,05 , maka hipotesis nihil yang menyatakan latihan dribble zig-zag bola basketsaat pretest dan postes menggunakan tiang serta latihan dribble zig-zag bola basket menggunakan kardus sama baiknya ditolak. Dengan melihat hasil thitung antara latihan dribble zig-zag bola basket menggunakan tiang lebih besar dibandingkan dengan latihan dribble zigzag bola basket menggunakan kardus. Dengan demikian, latihan dribble zig-zag bola basket menggunakan tiang lebih baik terhadap peningkatan keterampilan kecepatan dribble bola basket.

\section{PEMBAHASAN}

\section{Perbedaan Pengaruh Latihan Dribble Zig-zag terhadap Peningkatan Keterampilan Dribble Bola Basket Bagi Peserta Kegiatan Ekstrakurikuler Bola Basket SMA Nasional Malang}

Hasil uji hipotesis yang menggunakan uji analisis varian satu jalur pada kelompok latihan dribble zig-zag bola basket menggunakan tiang diperoleh $F_{\text {hitung }} 6,43$ lebih dari $F_{\text {tabel }}$ 4,17 dengan taraf signifikansi $\alpha$ sama dengan 0.05. Oleh karena $F_{\text {hitung }}$ lebih dari $F_{\text {tabel }}$, maka hipotesis nol ditolak dan hipotesis kerja yang menyatakan ada pengaruh latihan dribble zig-zag bola basket menggunakan tiang terhadap peningkatan keterampilan dribble bola basket diterima.

Dalam penelitian ini, peneliti telah memberikan perlakuan berupa latihan fisik, yaitu berupa latihan dribble zigzag menggunakan tiang, dengan intensitas latihan 55\% dan kenaikan beban latihan dilakukan setiap dua minggu sebesar $5 \%$. Hal ini sesuai dengan pendapat bahwa latihan adalah suatu proses yang sistematis dengan tujuan meningkatkan kesegaran jasmani seseorang atlet dengan suatu aktifitas yang dipilih, sedang pada umumnya masyarakat mengatakan latihan atau berlatih yang maksudnya untuk melakukan suatu kegiatan yang dilakukan secara berulang-ulang untuk menambah pengetahuan dan keterampilan (Marcolin, Camazzola, Panizzolo, Grigoletto, \& Paoli, 2018; Sopa \& Pomohaci, 2015). Latihan adalah proses melakukan kegiatan olahraga yang dilakukan berdasarkan program latihan yang disusun secara sistematis, bertujuan untuk meningkatkan kemampuan atlet dalam upaya mencapaiprestasi yang semaksimal mungkin, terutama dilaksanakan untuk persiapan menghadapi suatu pertandingan (Inglis \& Bird, 2016; Sopa \& Pomohaci, 2015). Sedangkan menurut ahli menyatakan bahwa latihan adalah proses dimana seorang atlet dipersiapkan untuk performa tertinggi (Carden, Izard, Greeves, Lake, \& Myers, 2017; Fernandez-Fernandez, Sanz, Sarabia, \& Moya, 2017). Dalam penelitian ini latihan dribble zig-zag bola basket dimodifikasi menjadi latihan dribble zigzag bola basket menggunakan tiang dikarenakan bahwa latihan yang panjang lebar dan terus-menerus atau kontinyu atas suatu kegiatan bisa sangat efektif dan pada keterampilan yang membutuhkan perubahan arah secara cepat, setiap gerakan harus dilakukan dengan cara yang terkendali (Arwih, 2019; Firmansyah, Syafaruddin, \& Victorian, 2019).

Didalam karakteristik dribble seorang pemain harus berusaha menghindari lawan dalam waktu yang cepat. Dari beberapa teknik gerakan dasar dalam permainan bola basket, salah satu teknik dasar yang sangat berpengaruh dalam permainan bola basket yaitu teknik dasar menggiring bola dribbling. Menggiring bola (dribble bola) adalah membawa dribble bola ke segala arah sesuai dengan peraturan yang ada (Franks, Miller, Bornn, \& Goldsberry, 2015; French \& Thomas, 2016). Menggiring bola (dribble bola) adalah upaya membawa bola dengan cara memantulkan bola di tempat, memantulkan bola sambil berjalan dan dribble memantulkan 
bola sambil dribble (Mahardika, 2016). Dari pendapat tersebut kelincahan menjadi faktor penting untuk meningkatkan keterampilan dribble siswa.

Kelincahan merupakan salah satu komponen fisik yang sangat diperlukan pada semua aktivitas yang membutuhkan kecepatan perubahan posisi tubuh dan bagian-bagiannya terutama dalam melakukan gerakan dribble bola basket, hal ini sesuai dengan pendapat bahwa kelincahan adalah kemampuan seseorang untuk mengubah arah dengan kecepatan dan tepat pada waktu bergerak tanpa kehilangan keseimbangan (Chaalali et al., 2016; Nimphius, Callaghan, Bezodis, \& Lockie, 2018; Spasic, Krolo, Zenic, Delextrat, \& Sekulic, 2015). Oleh karena itu, seseorang yang memiliki kelincahan yang baik dapat dengan mudah merubah posisi tubuhnya dengan tetap menjaga keseimbangan. Kelincahan adalah suatu bentuk gerakan yang mengharuskan seorang atau pemain untuk bergerak dengan cepat dan mengubah arah serta tangkas (Paul, Gabbett, \& Nassis, 2016; Young, Dawson, \& Henry, 2015). Pemain yang lincah adalah pemain yang bergerak tanpa kehilangan keseimbangan dan kesadaran akan posisi tubuhnya. Kelincahan terjadi karena gerakan tenaga yang eksplosif. Disamping itu kelincahan merupakan prasyarat untuk mempelajari dan memperbaiki keterampilan gerak dan teknik olahraga, terutama gerakan-gerakan yang membutuhkan koordisasi gerak. Kegunaan kelincahan adalah untuk mengkoordinasikan gerakan-gerakan berganda atau stimulan, mempermudah penguasaan teknik-teknik tinggi, gerakan-gerakan efisien, efektif dan ekonomis serta mempermudah orientasi terhadap lawan dan lingkungan (Scanlan, Tucker, \& Dalbo, 2014).

Latihan dribble zig-zag bola basket menggunakan tiang memiliki karakteristik dribble berkelok-kelok melewati rintangan. Hal ini sesuai dengan pendapat bahwa dribble zig-zag adalah suatu macam bentuk latihan yang dilakukan dengan gerakan berkelok-kelok melewati rambu-rambu yang telah di siapkan, dengan tujuan melatih kemampuan mengubah arah dengan cepat (Kerru, 2015; Udam, 2017). Siswantoyo (2003 : 20)“Dribble zig-zag adalah gerakan dribble berkelok-kelok mengikuti lintasan". Dribble zig-zag merupakan bentuk latihan dribble secepat cepatnya melalui lintasan yang berbelok belok dan kembali ke tempat star. Gerakan diulang sebanyak 6 sampai 8 kali(Torres-Ronda, Ric, Llabres-Torres, De Las Heras, \& Schelling I Del Alcazar, 2016). Daripendapat tersebut peneliti menyimpulkan bahwa dribble zig-zag adalah gerakan dribble yang dilakukan secara berkelok kelok sesuai dengan rintangan yang telah dipersiapkan.

Tujuan latihan dribble zig-zag adalah untuk menguasai keterampilan dribble, menghindar dari berbagai halangan baik orang maupun benda yang ada di sekeliling. Cara melakukan dribble bola dengan zig-zag yaitu peserta didik membawa dribble bola dengan dibble bola kemudian dribble berkelok-kelok mengikuti rintangan berupa tiang. Hasil penelitian ini didukung oleh hasil penelitian yang dilakukan oleh saudara Radjulani (2014:8) dalam penelitian ini terdapat peningkatan keterampilan dribble bola basket sehingga dapat disimpulkan ada pengaruh terhadap peningkatan keterampilan dribble bola basket dan terdapat perbedaan pengaruh antara kedua latihan dimana latihan dribble zig-zag bola basket menggunakan tiang mempunyai pengaruh lebih baik dari pada latihan dribble zig-zag bola basket menggunakan kardusdalam peningkatan dribble bola basket.

Radjulani (2014:48) menyimpulkan bahwa ada pengaruh latihan dribble zig-zag terhadap peningkatan kelincahan dribbling bola basket dan terdapat perbedaan pengaruh antara kedua pelatihan dimana latihan dribble zig-zag lebih baik dari pada latihan dogging run dalam peningkatan kelincahan dribbling bola basket. Merujuk pada penelitian yang telah dilakukan oleh Radjulani, maka dapat disimpulkan bahwa penelitian ini cukup relevan dengan penelitian terdahulu dikarenakan penelitian ini dapat digunakan untuk latihan meningkatkan keterampilan dribble bola basket dengan keterangan cukup valid sehingga latihan ini dapat digunakan. Berdasarkan penelitian tersebut dalam penelitian ini metode latihan dribble zig-zag menggunakan tiangberpengaruh signifikan terhadap peningkatan keterampilan dribble bola basket, dan latihan ini memiliki kelebihan dari penelitian sebelumnya, jika penelitian sebelumnya tanpa adanya halangan atau rintangan saat melakukan dribble zig-zag, maka dalam penelitian ini terdapat halangan berupa tiang, sehingga peneliti menyimpulkan jika tanpa adanya halangan dapat meningkatkan keterampilan dribble bola basket, maka dalam penelitian ini yang menggunakan tiang sebagai penghalang atau rintangan dapat meningkatkan keterampilan dribble basket.

Peningkatan keterampilan dribble bola basket peserta kegiatan ekstrakurikuler bola basket SMA Nasional Malang, sejalan dengan beberapa teori yang telah mendukung. Secara keseluruhan dapat dikemukakan bahwa peningkatan ketampilan dribble bola basket akibat dilakukannya salah satu metode latihan keterampilan yaitu latihan dribble zig-zag bola basket menggunakan tiang. Berdasarkan hasil keterampilan dribble bola basket yang dilakukan pada kelompok latihan dribble zig-zag bola basket menggunakan kardus 
ternyata latihan tersebut ada pengaruh yang signifikan terhadap peningkatan keterampilan dribble bola basket peserta kegiatan ekstrakurikuler bola basket SMA Nasional Malang.

\section{Perbedaan Pengaruh Latihan Dribble Zig-zag Terhadap Peningkatan Keterampilan Dribble Bola Basket Bagi Peserta Kegiatan Ekstrakurikuler Bola Basket SMA Nasional Malang}

Hasil uji hipotesis yang menggunakan uji analisis varian satu jalur pada kelompok latihan dribble zig-zag bola basket menggunakan kardus diperoleh $F_{\text {hitung }}$ 6,22 lebih dari $F_{\text {tabel }}$ 4,17 dengan taraf signifikansi a sama dengan 0.05 . Oleh karena $F_{\text {hitung }}$ lebih dari $F_{\text {tabel }}$ maka, hipotesis nol ditolak dan hipotesis kerja yang menyatakan ada pengaruh latihan dribble zig-zag menggunakan kardus terhadap peningkatan keterampilan dribble bola basket diterima.

Terjadinya peningkatan tersebut dikarenakan adanya suatu bentuk latihan fisik yang dilakukan untuk mencapai prestasi yang diinginkan. Latihan fisik yang diberikan peneliti dalam penelitian ini yaitu berupa latihan dribble zig-zag bola basket menggunakan kardus, dengan intensitas latihan $55 \%$ dan kenaikan beban latihan dilakukan setiap dua minggu sebesar $5 \%$. Hal ini sesuai dengan pendapat bahwa latihan fisik merupakan sebuah pendekatan yang terorganisasi untuk pelatihan fisik yang melibatkan siklus progresif dari berbagai aspek program pelatihan fisik selama periode waktu tertentu (National Physical Activity Plan Alliance, 2018; Piercy et al., 2018). Gray et al., (2015) latihan fisik adalah proses mengembangkan kemampuan aktivitas gerak jasmani yang dilakukan secara sistematik dan ditingkatkan secara progresif untuk mempertahankan atau meningkatkan derajat kebugaran jasmani agar tercapai kemampuan kerja fisik yang optimal. Sesuai dengan pendapat tersebut, dalam penelitian ini permainan bola basket merupakan cabang olahraga yang membutuhkan latihan fisik atlet dan jika dilakukan dengan baik mampu meningkatkan kemampuan keterampilan dribble bola basket.

Sama halnya dengan kelompok latihan dribble zig-zag bola basket menggunakan tiang, kelompok latihan dribble zig-zag bola basket menggunakan kardus merupakan latihan untuk meningkatkan keterampilan dribble bola basket. Latihan dribble zig-zag bola basket menggunakankardus memiliki karakteristik dribble yang dilakukan dengan mengikuti lintasan kardus secara berkelok-kelok. Tujuan dribble zig-zag bola basket adalah untuk menguasai keterampilan dribble, menghindar dari berbagai halangan baik orang maupun benda yang berada di sekeliling. (Yuwono \& Sugianto, 2015) tujuan dribble zig-zag bola basket adalah melatih merubah gerak tubuh arah berkelak-kelok.

Penelitian ini menggunakan media berupa kardus sebagai penghalang dalam melakukan gerak dribble zigzag bola basket. Adapun cara melakukan dribble zig-zag bola basket menggunakan kaedus yaitu peserta didik membawa dribble bola dengan dibble bola basket kemudian dribble berkelok-kelok mengikuti rintangan berupa kardus. Hasil penelitian ini didukung oleh hasil penelitian yang dilakukan oleh saudara Radjulani (2014:8) dalam penelitian ini terdapat peningkatan keterampilan dribble bola basket sehingga dapat disimpulkan ada pengaruh terhadap peningkatan keterampilan dribble bola basket.

Merujuk pada penelitian yang telah dilakukan oleh Radjulani, maka dapat disimpulkan bahwa penelitian ini cukup relevan dengan penelitian terdahulu dikarenakan penelitian ini dapat digunakan untuk latihan meningkatkan keterampilan dribble bola basket dengan keterangan cukup valid sehingga latihan ini dapat digunakan. Berdasarkan penelitian tersebut dalam penelitian ini metode latihan dribble zig-zag bola basket menggunakan tiangberpengaruh signifikan terhadap peningkatan keterampilan dribblebola basket, dan latihan ini memiliki kelebihan dari penelitian sebelumnya, jika penelitian sebelumnya tanpa adanya halangan atau rintangan saat melakukan dribble zig-zag bola basket, maka dalam penelitian ini terdapat halangan berupa kardus, sehingga peneliti menyimpulkan jika tanpa adanya halangan dapat meningkatkan keterampilan dribble bola basket, maka dalam penelitian ini yang menggunakan kardus sebagai penghalang atau rintangan dapat meningkatkan keterampilan dribble zig-zag bola basket.Peningkatan keterampilan dribble bola basket peserta kegiatan ekstrakurikuler bola basket SMA Nasional Malang, sejalan dengan beberapa teori yang telah mendukung. Secara keseluruhan dapat dikemukakan bahwa peningkatan ketampilan dribble bola basket akibat dilakukannya salah satu metode latihan keterampilanyaitu latihan dribble zig-zag bola basket menggunakan kardus. 


\section{Perbedaan Pengaruh Latihan Dribble Zig-zag Terhadap Peningkatan Keterampilan Dribble Bola Basket Bagi Peserta Kegiatan Ekstrakurikuler Bola Basket SMA Nasional Malang}

Hasil selisih uji hipotesis data skor prestasi tes awal dengan prestasi tes akhir latihan dribble zig-zag bola basket menggunakan tiang dengan latihan dribble zig-zag bola basket menggunakan kardus di peroleh $\mathrm{F}_{\text {hitung }}$ 4,235 lebih dari $F_{\text {tabel }}$ 4,17 dengan taraf signifikansi a sama dengan 0,05. Oleh karena $F_{\text {hitung }}$ lebih dari $F_{\text {tabel }}$ maka, hipotesis nol ditolak dan hipotesis kerja yang menyatakan ada pengaruh latihan dribble zig-zag menggunakan tiang dan latihan dribble zig-zag menggunakan kardus terhadap peningkatan keterampilan dribble bola basket diterima.

Dengan demikian latihan dribble zig-zag bola basket menggunakan tiang dan latihan dribble zig-zag bola basket menggunakan kardus dapat meningkatkan keterampilan dribble bola basket peserta kegiatan ekstrakurikuler bola basket SMA Nasional Malang. Karena ada pengaruh dilakukan uji lanjut berupa uji-t, yaitu bentuk uji-t sampel bebas (independen).

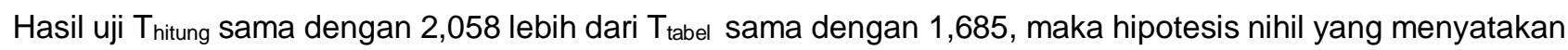
latihan dribblezig-zagbola basket menggunakan tiang dan latihan dribble zig-zag menggunakan kardussama baiknya ditolak. Hipotesis kerja yang menyatakan latihan dribble zig-zag bola basket menggunakan tiang lebih baik dibandingkan dengan latihan dribble zig-zag bola basketmenggunakan kardus diterima. Dengan demikian, latihan dribble zig-zag bola basket menggunakan tiang lebih baik terhadap peningkatan keterampilan dribble bola basket.

Penggunaan tiang dan kardus merupakan salah satu latihan koordinasi. Koordinasi adalah suatu kemampuan biomotorik yang sangat kompleks (Harsono, 1988). Koordinasi erat kaitannya dengan kecepatan, kekuatan, daya tahan, dan kelentukan (Fort-Vanmeerhaeghe, Romero-Rodriguez, Lloyd, Kushner, \& Myer, 2016; Komar, Chow, Chollet, \& Seifert, 2014). Oleh karena itu, bentuk latihan koordinasi harus dirancang dan disesuaikan dengan unsur-unsur kecepatan, kekuatan, daya tahan, dan kelentukan. Bentuk latihan koordinasi sebaiknya melibatkan berbagai variasi gerak dan keterampilan, seperti atlet bulutangkis sebaiknya jangan hanya latihan gerak dan keterampilan yang terdapat dalam aktivitas bulutangkis saja, namun berikan latihan-latihan gerak dan keterampilan yang terkandung dalam cabang-cabang olahraga lainnya seperti bola voli, bola basket, atau olahraga lainnya (satrio, 2011).

Dick (1989) kecepatan adalah kapasitas gerak dari anggota tubuh atau bagian dari sistem pengungkit tubuh atau kecepatan pergerakan dari seluruh tubuh yang dilaksanakan dalam waktu yang singkat. Terdapat dua tipe kecepatan yaitu: (a) Kecepatan reaksi adalah kapasitas awal pergerakan tubuh untuk menerima rangsangan secara tiba-tiba atau cepat, dan (b) Kecepatan bergerak adalah kecepatan berkontraksi dari beberapa otot untuk menggerakan anggota tubuh secara cepat. Dari kedua tipe kecepatan tipe di atas, tipe yang kedualah yang lebih diperlukan dalam kelincahan.

\section{KESIMPULAN}

Berdasarkan hasil analisis data dan pembahasan hasil penelitian yang dilakukan, maka hasil penelitian dapat disimpulkan bahwa: (1) Terdapat peningkatan kemampuan dribble bola basket untuk peserta kegiatan ekstrakurikuler SMA Nasional Kota Malang akibat latihan dribble zig zag bola basket dengan tiang pada taraf signifikansi a sama dengan 0,05. (2) Terdapat peningkatan kemampuan dribble bola basket untuk peserta kegiatan ekstrakurikuler SMA Nasional Kota Malang akibat latihan dribble zig zag bola basket menggunakan kardus pada taraf signifikansi a sama dengan 0,05. (3) Latihan dribble zig zag bola basket dengan tiang berpengaruh lebih baik terhadap peningkatan kemampuan dribble bola basket peserta ekstrakurikuler SMA Nasional Kota Malang dibandingkan dengan latihan dribble zig zag bola basket menggunakan kardus pada taraf signifikan a sama dengan 0,05 .

Berdasarkan hasil analisis data dengan temuan-temuan yang dihasilkan dalam penelitian ini, maka dapat dikemukakan saran bagi pelatih kegiatan ekstrakurikuler SMA Nasional Malang, bagi peserta kegiatan ekstrakurikuler SMA SMA Nasional Malang, dan bagi calon peneliti lainnya sebagai berikut: (1) Bagi Pelatih Ekstrakurikuler Bola baskket. Peneliti memberi saran kepada pelatih untuk memberikan latihan dribble zig zag bola basket menggunakan tiang dalam kegiatan pelatihan dikarenakan latihan dribble zig-zag menggunakan tiang lebih baik digunakan untuk meningkatkan kemampuan dribble bola basket pada peserta kegiatan ekstrakurikuler bola basket yang dapat digunakan pada atlet dalam kegiatan kemampuan dribble 
dibandingkan dengan latihan dribble zig-zag bola basket menggunakan kardus, maka pelatih eksperimen diharapkan perlu untuk mengupayakan pemberian latihan dribble zig-zag bola basket menggunakan tiang yang lebih intensif kepada para peserta kegiatan ekstrakurikuler di sekolah agar dapat memiliki prestasi yang maksimal. (2) Bagi Peserta Kegiatan Ekstrakurikuler Bola basket. Hasil penelitian ini diharapkan dapat digunakan sebagai bentuk latihan para peserta kegiatan ekstrakurikuler bola basket untuk meningkatkan kemampuan kemampuan dribble bola basket, terutama cabang olahraga yang dalam kinerjanya dipengaruhi atau tergantung pada kemampuan dribble zig-zag bola basket. (3) Bagi Calon Peneliti Lainnya. Dalam penelitian ini masih banyak kekuarangan yang terjadi, diharapkan melalui penelitian lain dapat disajikan sebagai bekal untuk mengkaji lebih dalam serta dikembangkan dalam bentuk penelitian lain dengan variabel bebas yang berbeda dengan subjek penelitian yang lebih luas.

\section{Ucapan Terima Kasih}

Puja dan puji syukur atas kehadirat Allah SWT, yang telah melimpahkan rahmat, inayah dan hidayah-Nya, sehingga penulis dapat menyelesaikan skripsi ini, dengan judul "Pengaruh Latihan Dribble Zig-zag Terhadap Peningkatan Keterampilan Dribble Bola Basket Bagi Peserta Kegiatan Ekstrakurikuler Bola Basket SMA Nasional Malang". Peneliti skripsi ini betujuan untuk memenuhi persyaratan akademik bagi setiap mahasiswa Universitas Negeri Malang dalam pencapaian gelar kesarjanaannya.

\section{DAFTAR PUSTAKA}

Ahmad, N. (2018). Pengaruh Latihan Zig Zag Run Terhadap Kelincahan Atlet Pencak Silat Tapak Suci Lebong. Journal Physical Education, Health and Recreation. https://doi.org/10.24114/pjkr.v2i2.9589

Arwih, M. Z. (2019). Hubungan Kelincahan Dengan Kemampuan Menggiring Pada Permainan Bolabasket Mahasiswa Jurusan IImu Keolahragaan Angkatan 2017 FKIP UHO. Jurnal IImu Keolahragaan, Fakultas IImu Keolahragaan, UNiversitas Negeri Medan.

Carden, P. P. J., Izard, R. M., Greeves, J. P., Lake, J. P., \& Myers, S. D. (2017). Force and acceleration characteristics of military foot drill: Implications for injury risk in recruits. BMJ Open Sport and Exercise Medicine. https://doi.org/10.1136/bmjsem-2015-000025

Chaalali, A., Rouissi, M., Chtara, M., Owen, A., Bragazzi, N. L., Moalla, W., ... Chamari, K. (2016). Agility training in young elite soccer players: Promising results compared to change of direction drills. Biology of Sport. https://doi.org/10.5604/20831862.1217924

Dionisius Wora, I Putu Adiatmika, Oktovianus Fufu, N.Adiputra, Made Muliarta, I. P. A. G. (2017). Pelatihan Zig-Zag Run Lebih Efektif Meningkatkan Kelincahan Menggiring Bola Dari Pada Pelatihan Shutlle Run Dalam Permainan Futsal. Sport and Fitness Journal.

Fernandez-Fernandez, J., Sanz, D., Sarabia, J. M., \& Moya, M. (2017). The effects of sport-specific drills training or high-intensity interval training in young tennis players. International Journal of Sports Physiology and Performance. https://doi.org/10.1123/ijspp.2015-0684

Firmansyah, M., Syafaruddin, S., \& Victorian, A. R. (2019). Kelincahan Dan Kecepatan Lari 30 Meter Dengan Kemampuan Dribble Ekstrakurikuler Bola Basket Di SMP. Altius : Jurnal Ilmu Olahraga Dan Kesehatan. https://doi.org/10.36706/altius.v6i2.8096

Fort-Vanmeerhaeghe, A., Romero-Rodriguez, D., Lloyd, R. S., Kushner, A., \& Myer, G. D. (2016). Integrative Neuromuscular Training in Youth Athletes. Part II: Strategies to Prevent Injuries and Improve Performance. Strength and Conditioning Journal. https://doi.org/10.1519/SSC.0000000000000234

Franks, A., Miller, A., Bornn, L., \& Goldsberry, K. (2015). Characterizing the spatial structure of defensive skill in professional basketball. Annals of Applied Statistics. https://doi.org/10.1214/14-AOAS799

French, K. E., \& Thomas, J. R. (2016). The Relation off Knowledge Development to Children's Basketball Performance. Journal of Sport Psychology. https://doi.org/10.1123/jsp.9.1.15

Garcia-Gil, M., Torres-Unda, J., Esain, I., Duñabeitia, I., Gil, S. M., Gil, J., \& Irazusta, J. (2018). Anthropometric parameters, age, and agility as performance predictors in elite female basketball players. Journal of 
Strength and Conditioning Research. https://doi.org/10.1519/jsc.0000000000002043

Gray, C., Gibbons, R., Larouche, R., Sandseter, E. B. H., Bienenstock, A., Brussoni, M., ... Tremblay, M. S. (2015). What is the relationship between outdoor time and physical activity, sedentary behaviour, and physical fitness in children? A systematic review. International Journal of Environmental Research and Public Health. https://doi.org/10.3390/ijerph120606455

Inglis, P., \& Bird, S. (2016). Reactive agility tests: review and practical applications. Journal of Australian Strength and Conditioning.

Kerru, A. A. S. A. S. B. (2015). Pengaruh Latihan Shuttle Run dan Lari Zig-zag Terhadap Keterampilan Dribbling dalam Permainan Bola Basket Pada Siswa SMP Negeri 1 Biromaru. Tadulako Physical Education, Health And Recreation.

Komar, J., Chow, J. Y., Chollet, D., \& Seifert, L. (2014). Effect of Analogy Instructions with an Internal Focus on Learning a Complex Motor Skill. Journal of Applied Sport Psychology. https://doi.org/10.1080/10413200.2013.771386

Mahardika, D. B. (2016). Pengaruh Metode Pembelajaran Latihan dan Motor Educability Terhadap Keterampilan Dribel Bola Basket. Jurnal Pendidikan Unsika.

Marcolin, G., Camazzola, N., Panizzolo, F. A., Grigoletto, D., \& Paoli, A. (2018). Different intensities of basketball drills affect jump shot accuracy of expert and junior players. PeerJ. https://doi.org/10.7717/peerj.4250

McCusker, K., \& Gunaydin, S. (2015). Research using qualitative, quantitative or mixed methods and choice based on the research. Perfusion (United Kingdom). https://doi.org/10.1177/0267659114559116

McNabb, D. E., \& McNabb, D. E. (2018). Fundamentals of Quantitative Research. In Research Methods for Public Administration and Nonprofit Management. https://doi.org/10.4324/9781315181158-9

National Physical Activity Plan Alliance. (2018). The 2018 United States Report Card on Physical Activity for Children and Youth. National Physical Activity Plan Alliance.

Nimphius, S., Callaghan, S. J., Bezodis, N. E., \& Lockie, R. G. (2018). Change of Direction and Agility Tests: Challenging Our Current Measures of Performance. Strength and Conditioning Journal. https://doi.org/10.1519/SSC.0000000000000309

Paul, D. J., Gabbett, T. J., \& Nassis, G. P. (2016). Agility in Team Sports: Testing, Training and Factors Affecting Performance. Sports Medicine. https://doi.org/10.1007/s40279-015-0428-2

Piercy, K. L., Troiano, R. P., Ballard, R. M., Carlson, S. A., Fulton, J. E., Galuska, D. A., ... Olson, R. D. (2018). The physical activity guidelines for Americans. JAMA - Journal of the American Medical Association. https://doi.org/10.1001/jama.2018.14854

Scanlan, A. T., Tucker, P. S., \& Dalbo, V. J. (2014). A comparison of linear speed, closed-skill agility, and open-skill agility qualities between backcourt and frontcourt adult semiprofessional male basketball players. Journal of Strength and Conditioning Research. https://doi.org/10.1519/JSC.0000000000000276

Sopa, S., \& Pomohaci, M. (2015). Testing agility skill at a basketball team (10-12 years old). Conference Paper.

Spasic, M., Krolo, A., Zenic, N., Delextrat, A., \& Sekulic, D. (2015). Reactive agility performance in handball; development and evaluation of a sport-specific measurement protocol. Journal of Sports Science and Medicine.

Torres-Ronda, L., Ric, A., Llabres-Torres, I., De Las Heras, B., \& Schelling I Del Alcazar, X. (2016). PositionDependent Cardiovascular Response and Time-Motion Analysis During Training Drills and Friendly Matches in Elite Male Basketball Players. Journal of Strength and Conditioning Research. https://doi.org/10.1519/JSC.0000000000001043

Udam, M. (2017). Pengaruh Latihan Shuttle-Run dan Zig-zag terhadap Kemampuan Dribbling Bola pada Siswa Sekolah Sepakbola (SSB) Imanuel USia 13-15 di Kabupaten Jayapura. Jurnal Pendidikan Jasmani Olahraga Dan Kesehatan. 
Young, W. B., Dawson, B., \& Henry, G. J. (2015). Agility and change-of-direction speed are independent skills: Implications for training for agility in invasion sports. International Journal of Sports Science and Coaching. https://doi.org/10.1260/1747-9541.10.1.159

Yuwono, E. I., \& Sugianto, N. (2015). Rancang Bangun Permainan Dribel Bola Basket "Basketball Jam” Untuk menggunakan Knect. Universitas Ciputra, Surabaya. 